ARTUR ADAMCZYK

DOI : $10.14746 /$ rie.2017.11.19

Centrum Europejskie Uniwersytetu Warszawskiego

\title{
Quo Vadis Turcjo - koniec europejskiego kierunku w polityce zagranicznej Turcji?
}

\section{Wprowadzenie}

Głównym celem artykułu jest analiza ewolucji europejskiego kierunku w polityce zagranicznej Turcji w sytuacji zmieniającego się jej otoczenia międzynarodowego. Charyzmatyczny przywódca Republiki Tureckiej Kemal Pasza Atatürk, ustalając fundamenty polityczne i społeczne funkcjonowania młodego państwa w 1923 r. wyraźnie wskazał na westernizację, jako główny priorytet rozwoju Turcji. Westernizację należy rozumieć jako modernizację kraju realizowaną w oparciu o rozwiniętą i pogłębioną współpracę z państwami europejskimi (Gonlübol, 1971, s. 13). To właśnie wdrażanie rozwiązań wprowadzających zasady demokracji i sekularyzacji, bazujących na wzorcach europejskich miało zagwarantować młodej republice konwersję w silne, laickie i narodowe państwo powstałe na gruzach Imperium Otomańskiego. Młoda Turcja odrzuciła zatem islamską spuściznę Otomanów, kojarzoną z despotyzmem i zacofaniem na rzecz systematycznego wdrażania zachodnich wartości. Były to zmiany społeczne i polityczne o charakterze rewolucyjnym, które rzutowały na kształtowanie polityki zagranicznej Turcji aż do końca XX wieku. W konsekwencji Turcja zacieśniała swoje stosunki z państwami europejskimi, natomiast ograniczała relacje z państwami sąsiadującymi na wschodzie. Ankara chciała w ten sposób pokazać, że ,zrywa” ze swoją bliskowschodnią tożsamością i staje się państwem w pełni europejskim. Politycy tureccy postrzegali swoich wschodnich sąsiadów za państwa gorszej kategorii, zacofanych gospodarczo, niestabilnych politycznie i niegodnych zaufania. Ankara oskarżała społeczeństwa arabskie o zdradę i zadanie „ciosu w plecy” Imperium Otomańskiemu w czasie pierwszej wojny światowej, co m.in. miało przyczynić się do jego upadku. Należy podkreślić, że także państwa arabskie w okresie międzywojennym bardzo sceptycznie odnosiły się do zacieśniania relacji z Turcją, obawiając się odbudowania potęgi tureckiej w regionie (Martin, 2004, s. 161). Jak twierdzi Joanna Sztubert „główną cechą państwowości tureckiej stał się nacjonalizm, a jedną z metod jego propagowania i umacniania była dyskryminacja języka i kultury arabskiej” (Sztubert, 2011, s. 157).

W trakcie drugiej wojny światowej Turcja zadeklarowała swoją neutralność, utrzymywała jednak bliskie relacje zarówno z państwami Osi, jak i aliantami, konsekwentnie zabiegając o ścisłe związki z krajami europejskimi. Do wojny po stronie aliantów przystapiła dopiero w końcowej fazie konfliktu, w lutym 1945 r., kiedy kres Trzeciej Rzeszy został właściwie przypieczętowany (Cyr, 2015, s. 226). 


\section{Kierunek zachodni w polityce zagranicznej Turcji w czasie Zimnej Wojny}

Podział globu na dwa bloki po zakończeniu drugiej wojny światowej zmusił Turcję do opowiedzenia się po stronie państw zachodnich. Po pierwsze, przyczyniła się do tego agresywna polityka Związku Radzieckiego żądającego udostępnienia cieśnin czarnomorskich dla tworzenia tam baz militarnych ZSRR (Gonlübol, 1971, s. 12-14). Po drugie, związki z państwami zachodnioeuropejskimi były kontynuacją koncepcji kształtowania polityki zagranicznej Turcji, pozostawionej w politycznym testamencie Atatürka. Ponieważ przywódcą świata demokratycznego zostały Stany Zjednoczone, które ściśle współpracowały z państwami Europy Zachodniej, proces westernizacji Turcji opierał się na ścisłych związkach nie tylko z krajami europejskimi, ale, co było naturalne, $\mathrm{z}$ liderem bloku, czyli USA. Współpraca z tą grupą państw była oczywistą przeciwwagą i zarazem poszukiwaniem gwarancji bezpieczeństwa wobec agresywnej polityki ZSRR.

Przewaga USA w początkowej konfrontacji zimnowojennej, wynikająca z faktu posiadania broni nuklearnej, szybko została zniwelowana przez radzieckie osiągnięcia w tej dziedzinie. Po wyprodukowaniu broni atomowej przez ZSRR rywalizacja między dwoma blokami oparła się na wyścigu zbrojeń i budowie przewagi w zakresie broni konwencjonalnej. Posiadanie baz militarnych na terenie Turcji oraz rozbudowa jej armii i arsenału wiązało wojska radzieckie w tym regionie podkreślając znaczenie Turcji w systemie bezpieczeństwa państw zachodnich. Korzyści z przynależności Turcji do bloku zachodniego leżały zatem nie tylko po stronie Ankary. Posiadanie takiego sojusznika jak Turcja wzmacniało także pozycję międzynarodową Stanów Zjednoczonych i europejskich partnerów. Do głównych atutów Turcji należy zaliczyć jej strategiczne położenie - kontrolowała morskie szlaki komunikacyjne z Morza Czarnego na Morze Śródziemne, stanowiła także bufor ograniczający ekspansję wpływów Związku Radzieckiego w krajach arabskich. Była także postrzegana przez państwa zachodnie jako potencjalny lider w regionie bliskowschodnim, wokół którego USA i Wielka Brytania chciały zbudować antyradziecki sojusz państw muzułmańskich (Altunisik, 2013, s. 158). Wyrazem tego było podpisanie Paktu Bagdadzkiego (1955) oraz jego kontynuacja, czyli powołanie Organizacji Paktu Centralnego (CENTO 1959-79). Należy podkreślić, że Turcja ze względu na swoją laickość i współpracę z Izraelem nie była jednak predestynowana do pełnienia roli przywódcy w świecie islamskim. Ankara podchodziła także z wyraźnym dystansem do państw muzułmańskich, gdyż te w późniejszym okresie nie poparły Ankary na arenie międzynarodowej w kwestii cypryjskiej (Martin, 2004, s. 160). Sami politycy tureccy wyraźnie akcentowali wolę zacieśniania związków z Zachodem niż z państwami tego regionu. Wyrazem tych ambicji była decyzja Turcji o wstapieniu do Rady Europy (1949 r.) oraz do Paktu Północnoatlantyckiego (1952 r.). Ankara także dążyła do nawiązania bliskiej współpracy ekonomicznej z utworzonymi w latach 50. XX w. Wspólnotami Europejskimi (Milczarek, Barburska, 2013). Przyczyniło się to do podjęcia w 1959 r. starań o uzyskanie statusu państwa stowarzyszonego z Europejską Wspólnotą Gospodarczą, który został zwieńczony sukcesem cztery lata później. Uzyskanie tego 
statusu wynikało głównie z faktu postrzegania Turcji przez członków Wspólnot Europejskich jako strategicznie ważnego sojusznika w okresie zimnowojennej konfrontacji (Osiewicz, 2015, s. 200).

W kolejnych dekadach doszło jednak do nadwyrężenia relacji Ankary z zachodnimi sojusznikami. Pierwsze spięcie miało miejsce w czasie kryzysu cypryjskiego w 1964 r., kiedy Turcja zagroziła inwazją na tę wyspę. Prezydent USA L. Johnson ostrzegł wówczas Turcję, że jej egoistyczne zachowanie, które narusza spójność sojuszu może sprowokować militarną reakcję ZSRR. Zachodni sojusznicy w takiej sytuacji mogą nie czuć się zobligowani do przyjścia z pomocą Turcji w ramach art. 5 Traktatu Waszyngtońskiego. To był pierwszy sygnał dla Ankary, po którym zaczęła redefiniować soją politykę zagraniczną, zdając sobie sprawę, że bardziej musi zadbać o swoje własne interesy, nie rezygnując oczywiście ze związków z Zachodem (Gonlübol, 1971, s. 6).

Kolejne wydarzenia, takie jak zamachy stanu w latach 1971 i 1980 oraz inwazja militarna na Cypr w 1974 r. nadwyrężyły jeszcze bardziej relacje pomiędzy Turcją a zachodnimi sojusznikami (Osiewicz, 2013; Misztal 2013; Adamczyk 2002). Nałożenie przez USA embarga na dostawy broni do Turcji po inwazji na Cypr zostało potraktowane przez polityków znad Bosforu jako swoista zdrada i naruszenie zasady solidarności (Outzen, 2012, s. 2). Turcja oczywiście pozostała członkiem NATO ze względu na zagrożenie ze strony ZSRR oraz współpracowała ze Wspólnotami Europejskimi, jednak jej spór z Grecją i Cyprem przełożył się na kształtowanie negatywnej opinii o Turcji wśród zachodnich sojuszników. Polepszenie relacji Ankary z Zachodem nastapiło dopiero po inwazji radzieckiej na Afganistan oraz rewolucji islamskiej w Iranie w 1979 r. Turcja ponownie zyskała na znaczeniu dla USA i państw zachodnioeuropejskich (Criss, 2013, s. 150). Jednak jej relacje ze Wspólnotami Europejskimi wyraźnie wyhamowały po 1981 r., kiedy to Grecja uzyskała status członka we Wspólnotach. Ateny stały się „głównym hamulcowym” w procesie zacieśniania relacji między Ankarą a Brukselą. Grecja pozostaje w permanentnym sporze z Turcją o delimitację Morza Egejskiego oraz państwem popierającym Republikę Cypryjską w konflikcie z Ankarą (Osiewicz, 2006; Adamczyk, 2009).

Turcja po zaostrzeniu konfrontacji zimnowojennej w latach 80. ponownie starała się wykorzystać swoją silną pozycję polityczną w regionie i złożyła, w 1987 r., wniosek o pełne członkostwo we Wspólnotach Europejskich. Jednak opinia Komisji Europejskiej wydana w 1989 r. była negatywna. Po pierwsze Bruksela wskazała, że Wspólnoty są ,zmęczone” ostatnim rozszerzeniem o Hiszpanię i Portugalię oraz, że są w trakcie przygotowania Wspólnego Rynku, a na tym etapie przyjęcie nowego państwa byłoby bezzasadne. Po drugie uznano, że Turcja nie jest gotowa na członkostwo głównie ze względu na nieprzestrzeganie zasad demokracji i rządów prawa. W tle decyzji był także sprzeciw Grecji, która żądała, aby Turcja najpierw wycofała swoje wojska z Cypru. Jak słusznie twierdzi Jakub Wódka „,europejskie aspiracje Ankary w dobie zimnowojennej nie były głównym determinantem jej polityki zagranicznej, nie warunkowały działań podejmowanych przez nią na arenie międzynarodowej. Tureckie elity postrzegały członkostwo we Wspólnotach Europejskich jako dopełnienie politycznego zaangażowania w NATO” (Wódka, 2013, s. 26). 


\section{Polityka europejska Turcji po rozpadzie układu dwublokowego}

Rozpad układu dwublokowego był wielkim wyzwaniem dla polityków tureckich, którzy obawiali się, że brak głównego zagrożenia, jakim był Związek Radziecki przyczyni się do erozji znaczenia Turcji dla państw zachodnich. W konsekwencji nowa sytuacja międzynarodowa mogła doprowadzić do izolacji Turcji, a nawet porzucenia tego kraju, jako niepotrzebnego już partnera w tym regionie. Turcja mogła wówczas poczuć się osamotniona w sytuacji pojawiających się nowych problemów związanych z niestabilnym sąsiedztwem, skonfliktowanymi młodymi państwami na Kaukazie oraz tradycyjnie nieprzewidywalnymi krajami Bliskiego Wschodu. Z pewnością pierwsze wrażenie takiego porzucenia mógł wzbudzić także fakt odmowy nadania członkostwa Turcji we Wspólnotach Europejskich w 1989 r. (Guvenc, Ozel, 2012, s. 536).

Wkrótce okazało się, że w kształtującym się nowym układzie sił Turcja pozostaje wciąż ważnym ogniwem w systemie bezpieczeństwa dla dotychczasowych sojuszników. W czasie pierwszej wojny w Zatoce Perskiej (1990-1991) Stany Zjednoczone wraz z koalicjantami poprosiły o pomoc Turcję, która udostępniła swoje bazy oraz przestrzeń powietrzną nad swoim terytorium w celu walki z reżimem Saddama Husajna (Altunisik, 2013, s. 160). Wydawało się, że Ankara odbudowała swoją pozycję jako ważnego partnera dla świata Zachodu, jednak wsparcie USA dla bojowników kurdyjskich w Iraku wyraźnie zaniepokoiło polityków tureckich. Zaczęli z większym dystansem odnosić się do poczynań USA w regionie, dostrzegając, że priorytety amerykańskie stoją w sprzeczności z interesami bezpieczeństwa Turcji. W czasie drugiej wojny w Zatoce Perskiej, która rozpoczęła się w 2003 r. Turcja odmówiła wsparcia Amerykanom argumentując tę decyzję własnymi interesami narodowymi i negatywnymi doświadczeniami wynikającymi z pierwszej wojny w zatoce. Sojusz tureckoamerykański zaczął ulegać erozji. Natomiast polityka turecka wkomponowała się w postawę najważniejszych członków Unii Europejskiej, którzy skrytykowali interwencje USA w Iraku (Buhari, 2009, s. 93).

Należy podkreślić, że lata 90. XX w. to okres usamodzielniania się Unii Europejskiej na arenie międzynarodowej. Państwa europejskie pozostające przez całe dekady w sojuszu ze Stanami Zjednoczonymi zadecydowały o podkreśleniu własnej roli i pozycji w świecie i stworzeniu Wspólnej Polityki Zagranicznej i Bezpieczeństwa w ramach UE. Ankara, widząc wzrost znaczenia państw europejskich oraz ambicje budowania z Unii Europejskiej gracza globalnego, równorzędnego Stanom Zjednoczonym, za główny cel swojej polityki zagranicznej obrała drogę do pełnego członkostwa w tej europejskiej strukturze.

W ramach realizacji tego celu Ankara rozpoczęła starania o zawarcie Umowy o Unii Celnej z Unią Europejską, która uzyskała swój ostateczny kształt w 1994 r. (Ambroziak, 2014, s. 241-255). Początkowo implementacja tej umowy była blokowana przez Grecję, jednak zagwarantowanie przez Brukselę nadania statusu kandydata do UE Republice Cypryjskiej złagodziło greckie veto i umowa weszła w życie w 1995 r. (Agnantopoulos, 2013, s. 73). W efekcie implementacji unii celnej gwałtownie wzrosła wymiana gospodarcza pomiędzy Turcją i UE. Państwa członkowskie UE stały się głównym partnerem handlowym dla Turcji (Zajączkowski, 2011, s. 70-88). 
Kiedy w 1998 r. Rada Europejska zadecydowała o rozpoczęciu negocjacji akcesyjnych z tzw. grupą luksemburską, do której należała także Republika Cypryjska, rząd w Ankarze wyraził swoje niezadowolenie i zasygnalizował Brukseli możliwość rezygnacji z aspiracji członkowskich w UE. Niezadowolenie Turcji wynikało z dwóch faktów. Po pierwsze, Cypr jako potencjalny członek UE mógł zablokować dalszy proces integracji Turcji z UE, po drugie, Unia rozpoczęła negocjacje akcesyjne z państwami, które daleko później uzyskały status stowarzyszenia niż Turcja. Politycy unijni wyraźnie wskazywali, iż ich decyzja związana jest z faktem przeprowadzenia daleko bardziej zaawansowanych reform przez kraje zaproszone do negocjacji niż Turcja, równocześnie podjęli wysiłki w celu złagodzenia złych relacji z Ankarą. W efekcie w 1999 r. w czasie szczytu Rady Europejskiej w Helsinkach przyznano Turcji status kandydata. Ponowne napięcia pomiędzy Brukselą a Ankarą wystąpiły po przyjęciu Cypru do UE w ramach wielkiego rozszerzenia, które miało miejsce w 2004 r. Ponownie Bruksela postanowiła zrekompensować polityczne upokorzenie Turcji, ogłaszając w grudniu 2004 r., że Turcja wypełniła tzw. kryteria kopenhaskie i rok później rozpoczęto z nią negocjacje akcesyjne (Szymański, 2011). Pomimo upływu już 12 lat od czasu ich rozpoczęcia nie osiagnięto większych postępów w procesie negocjacyjnym, głównie ze względu na bilateralny spór Turcji z Republiką Cypru (Osiewicz, 2015). Do tej pory otworzono łącznie 16 rozdziałów, z czego tymczasowo zamknięto tylko jeden. Nikozja blokuje otwarcie kolejnych, żądając dla siebie uznania międzynarodowego przez rząd turecki oraz wycofania wojsk okupacyjnych z północy wyspy ${ }^{1}$.

Brak rozwiązania problemu cypryjskiego nie jest jedynym z argumentów wysuwanych przez przeciwników akcesji Turcji do UE. Fala ostatnich akcesji wywołała zjawisko zmęczenia rozszerzeniem (enlargement fatigue) wśród społeczeństwa i części polityków europejskich, którzy utożsamiają je z osłabieniem spójności UE. Jakoby na potwierdzenie tych odczuć UE przeżywała kryzys finansowy, któremu towarzyszyła możliwość GREXITU, pojawiły się także bardzo silne ruchy nacjonalistyczne, które zaczęły negować ideę pogłębiania integracji europejskiej, co w efekcie doprowadziło do uruchomienia procesu BREXITU. Zjawiska, które miały miejsce po wielkiej akcesji z 2004 r. przyczyniły się do wywołania fali sceptycyzmu wśród społeczeństw starej „15" wobec słuszności tej decyzji, a tym samym wobec dalszego procesu rozszerzenia. Tym bardziej możliwość przystąpienia Turcji do UE wywołuje szczególnie negatywne emocje. Przeciwnicy tego procesu podkreślają, że całkowicie odmienna kulturowo i religijnie Turcja nie pasuje do Unii Europejskiej i jej obecność w UE będzie fatalnym końcem idei integracji europejskiej. Dlatego też w celu uniemożliwienia tej akcesji część polityków europejskich przygotowała całą serię argumentów i warunków utrudniających wejście Turcji do UE. Do najważniejszych, oprócz problemu cypryjskiego, należą: przyznanie się Ankary do ludobójstwa Ormian w czasie pierwszej wojny światowej, poszanowanie praw mniejszości kurdyjskiej, rozwiązanie problemu delimitacji Morza Egejskiego pomiędzy Grecją i Turcją. W niektórych krajach takich jak Austria i Francja rozważa się przeprowadzenie referendum w sprawie ewentualnej akcesji Turcji do UE, oczywiście zakładając, że większość społeczeństwa tych krajów jest negatywnie nastawiona do tego rozszerzenia. Oczywiście są to argumenty, które

${ }^{1}$ Turcja nie uznaje na arenie międzynarodowej Republiki Cypryjskiej. Uznaje natomiast samozwańczą Turecką Republikę Północnego Cypru, na terenie której stacjonują wojska tureckie. 
pojawiają się głównie nieoficjalnie w retoryce polityków europejskich. Oficjalną przeszkodą na drodze Ankary do UE jest wciąż brak przygotowania tego kraju do członkostwa i przede wszystkim brak spełnienia standardów unijnych.

Turcja w kolejnych ocenach przygotowywanych przez Komisję Europejską jest krytykowana za zaniechanie pro-europejskich reform, szczególnie w zakresie praw człowieka i ochrony mniejszości. Zdaniem Adama Szymańskiego do głównych zastrzeżeń można zaliczyć stosowanie tortur i przemocy, naruszanie wolności słowa, sumienia i wyznania. Kolejne zarzuty dotyczą braku przestrzegania zasady równouprawnienia kobiet i mężczyzn oraz wolności stowarzyszania się (Szymański, 2008, s. 73).

W ostatnich opiniach Komisji Europejskiej na temat stanu przygotowań Turcji do akcesji w zakresie kryteriów politycznych wyraźnie podkreślono spowolnienie tempa reform, a w szczególności kwestii uregulowania problemu kurdyjskiego. Ocena umiarkowana została przyznana w dziedzinie reformy administracji publicznej, wytknięto ingerencję w niezależność sądownictwa. Turcja jest w niewielkim stopniu przygotowana do zwalczania korupcji i przestępczości zorganizowanej. Wskazano na uchybienia $\mathrm{w}$ zakresie egzekwowania praw wynikających z europejskiej konwencji praw człowieka i orzecznictwa Europejskiego Trybunału Praw Człowieka. KE skrytykowała także Turcję za regres w dziedzinie wolności słowa i wolności zgromadzeń, dotyczy to szczególnie zmian w zakresie Internetu (blokowanie treści), wytaczaniu spraw karnych przeciwko dziennikarzom. W zakresie kryteriów ekonomicznych uznano, że gospodarka Turcji jest „w zaawansowanym stopniu przygotowana i można ją uznać za sprawną gospodarkę rynkową" (Strategia, 2015). Jest także dobrze przygotowana do sprostania konkurencji i siłom rynkowym UE. Ostateczna opinia Komisji wskazywała jednak, iż Turcja nie jest gotowa do członkostwa.

Negatywne opinie Komisji Europejskiej oraz wzrastające nieprzychylne nastroje społeczeństw państw europejskich wobec ewentualnej akcesji Turcji przyczyniły się do zniechęcenia polityków tureckich do podejmowania dalszych wysiłków reformujących kraj wg wzorców europejskich. Prezydent Recep Tayyip Erdoğan wyraźnie dał Brukseli do zrozumienia, iż członkostwo w UE nie jest jedynym rozwiązaniem dla przyszłości Turcji, a jego kraj może obrać inne priorytety i inne kierunki w ramach budowania silnej pozycji Turcji w regionie.

\section{Nowe kierunki w polityce zagranicznej Turcji - alternatywa dla kierunku europejskiego?}

Deklaracje Erdoğana dotyczące rezygnacji z kierunku europejskiego i obrania nowych priorytetów w polityce zagranicznej Turcji nie pojawiły się nagle. Rozpad układu dwublokowego i pojawienie się nowych republik na gruzach ZSRR, których społeczeństwa $\mathrm{w}$ przeszłości były powiązane $\mathrm{z}$ wpływami otomańskimi otworzyło nowe możliwości budowania kontaktów przez Ankarę. Także rozpad Jugosławii i powstanie tam nowych państw, w których funkcjonują społeczeństwa muzułmańskie zostało odebrane przez polityków znad Bosforu jako szansa na kształtowanie nowych relacji z tym regionem. W pierwszej połowie lat 90 . XX w. prezydent Turcji Tur- 
gut Ozal, a następnie premier Sulejman Demirel głosili ideę budowania ,,tureckiego świata rozciagajacego się od Adriatyku do wielkiego muru w Chinach”" (Tuysuzoglu, 2014, s. 90). Ozal wyrażał przekonanie, że Turcja może pełnić funkcję modelu rozwiązań politycznych oraz gospodarczych dla państw powstałych po rozpadzie ZSRR i zarazem doradzać tym państwom w zakresie przeprowadzania reform (Aydin, 2014, s. 385). To oczywiście implikowałoby większe zaangażowanie Turcji na Kaukazie, Azji Środkowej oraz na Bałkanach i wzmocniło jej pozycję międzynarodową, a tym samym podkreśliło jej znaczenie dla zachodnich partnerów. W retoryce polityków tureckich zaczęły pojawiać się hasła określające Turcję jako państwo euroazjatyckie, podkreślano znaczenie wspólnych wartości kulturowych, religijnych i historycznych, które umożliwiłyby budowanie szerszej współpracy w regionie pod przywództwem Turcji. W kręgach akademickich zaczęto ten kierunek w polityce zagranicznej Turcji określać jako neo-otomanizm, choć to określenie nie było używane przez samych polityków w obawie o wywołanie negatywnego oddźwięku wśród sąsiadów mogących oceniać tę aktywność jako turecki neoimperializm.

Kiedy w 2002 r. wybory parlamentarne w Turcji wygrała Partia Sprawiedliwości i Rozwoju (AKP) jej lider Erdoğan wyraził wolę kontynuowania tego kierunku w polityce zagranicznej państwa. Głównym architektem nowej doktryny dyplomacji tureckiej nazwanej „strategiczną głębią” został Ahmet Davutoglu, późniejszy minister spraw zagranicznych i premier Turcji. Jak podkreśla Tomasz Stępniewski „,zgodnie z założeniami tej doktryny, polityka zewnętrzna Turcji powinna opierać się na dwóch wymiarach: historycznym i geograficznym. W przypadku wymiaru historycznego [...], Turcja powinna odwoływać się do spuścizny Imperium Otomańskiego [...] Z kolei wymiar geograficzny oznacza, że Turcja powinna uwzględniać uwarunkowania geopolityczne w konstruowaniu polityki zagranicznej" (Stępniewski, 2011, s. 45). W Ankarze zaczęto podkreślać, że dzięki geopolitycznemu położeniu Turcja jest nie tylko graczem regionalnym, ale jest predestynowana do roli państwa położonego w centrum świata - państwa środkowego. Dzięki swojej lokalizacji kraj ten może odgrywać istotną rolę na Bałkanach, Kaukazie, Bliskim Wschodzie, Azji Środkowej, w Zatoce Perskiej, w basenie Morza Śródziemnego, Morza Czarnego i Kaspijskiego - jest strategicznym centrum Eurazji. Zdaniem Davutoglu dotychczasowa polityka Turcji była zawężona do ścisłej współpracy z państwami zachodu, Turcja się samoograniczała i niedoceniała swojego potencjału wynikającego z lokalizacji (Yesilyurt, Akdevelioglu, 2009, s. 40). Turcja pozwoliła się zdegradować do roli państwa, które było wykorzystywane w grze wielkich mocarstw, które było użyte do promowania interesów innych sił w swoim otoczeniu. Strategiczna głębia miała stanowić nowe otwarcie w polityce zagranicznej Turcji, która miała rozpocząc realizację własnych interesów i wykorzystywać swoje położenie do promowania własnej wizji kształtowania otoczenia międzynarodowego, jako mocarstwa regionalnego i globalnego (Grigoriadis, 2014, s. 161). Głównym elementem doktryny Davutoğlu, była zasada „zero problemów z sąsiadami”, której realizacja miała umocnić wizerunek Turcji jako państwa stabilnego i przewidywalnego, atrakcyjnego dla swoich sąsiadów i dalszych partnerów. W tym celu Turcja zamierzała użyć swoich atrybutów soft policy, czyli wykorzystać kontakty ekonomiczne i kulturowe, aby uzyskać jak największe wpływy w swoim otoczeniu. 
Decyzja o redefinicji kierunków polityki zagranicznej Turcji zbiegła się z osłabieniem relacji tego państwa z USA oraz Unią Europejską. Pogorszenie kontaktów z Waszyngtonem nastapiło w efekcie braku poparcia dla inwazji USA na Irak w 2003 r., z kolei regres w stosunkach z Brukselą nastapił po 2006 r., kiedy UE zamroziła proces negocjacji akcesyjnych ze względu na sprzeciw Cypru i Francji (Szymański, 2011, s. 15). Pogorszenie tych relacji nie oznaczało oczywiście, że Turcja rezygnuje z tych kierunków polityki zagranicznej i odwraca się plecami do Zachodu. Davutoglu chciał dać jednak politykom europejskim i amerykańskim do zrozumienia, że Turcja nie jest „skazana” tylko na współpracę z nimi, ale ma inne możliwości. Polityk ten podkreślał, że „Turcja może być europejska w Europie i wschodnia na Wschodzie” (Gunay, Renda, 2014, s. 53). Koncepcje Davutoglu były wspierane przez innych polityków związanych z AKP, między innymi ówczesnego prezydenta Gula, który stwierdził, że „Turcja to nowoczesny kraj Eurazji, który łączy Wschód i Zachód i któremu pomyślnie udało się połączyć kulturę i wartości obu cywilizacji. Nasze korzenie w Azji Centralnej i interakcje ze światem zachodnim, które sięgają wieków, dają nam wyjątkową sytuację pełnej przynależności do obu kontynentów w tym samym czasie" (Yanik 2011, s. 80).

Analizując efektywność rządów AKP w pierwszej dekadzie XXI w. można odnieść wrażenie, że wdrażanie doktryny Davutoglu zaczyna przynosić Turcji same sukcesy. Polepszenie stosunków bilateralnych $\mathrm{w}$ regionie połączone $\mathrm{z}$ bardzo dobrą sytuacją ekonomiczną tego kraju, spowodowało wzrost międzynarodowej pozycji Turcji i postrzegania jej przez otoczenie jako mocarstwa regionalnego. W ramach realizacji „soft power” i odwoływania się do wspólnej historii i kultury Turcja zainaugurowała współpracę z turkmeńskimi republikami postsowieckimi z Azji Środkowej. W 2010 r. powołano Radę Współpracy Państw Turkmeńskich, do której obok Turcji należą Azerbejdżan, Turkmenistan, Kazachstan, Kirgistan i Uzbekistan (Barrinha, 2014, s. 175).

Na szczególną uwagę zasługują stosunki z państwami Bliskiego Wschodu, które przez całe dekady były traktowane przez Turcję z dystansem ze względu na permanentną niestabilność regionu. Davutoglu podkreślił, że jeżeli Ankara chce być graczem liczącym się w regionie musi zerwać z dotychczasową polityką. Architekt tureckiej strategicznej głębi stwierdził, że ,jeżeli Turcja nie podejmie aktywnej roli na Bliskim Wschodzie to Bliski Wschód będzie aktywny w Turcji” (Yesilyurt, Akdevelioglu, 2009, s. 41). W rezultacie rząd w Ankarze wzmocnił swoje relacje z Syrią, rozwijając kontakty zarówno w sferze ekonomicznej, jak i militarnej. Także stosunki z Iranem uległy normalizacji, dzięki czemu Turcja podpisała wiele kontraktów na dostawy węglowodorów z tego kraju. Najważniejszym partnerem handlowym w regionie stał się Irak, a w zasadzie autonomiczny region Kurdystanu w północnym Iraku, gdzie Turcja ulokowała wiele inwestycji bezpośrednich. Zacieśnienie współpracy Ankary z Bagdadem i Damaszkiem przyczyniło się do stworzenia Rad Współpracy Strategicznej, które na wzór Unii Europejskiej miały być forum konsultacji ministrów trzech państw w zakresie rozwiązywania problemów w regionie. Turcja konsekwentnie zacieśniała relacje bilateralne, ale także dążyła do przywództwa regionalnego. W rezultacie porozumień bilateralnych z Syrią, Libią, Jemenem, Libanem i Jordanią wprowadzono wymianę bezwizową, która miała wzmocnić wizerunek Turcji w otoczeniu dzięki większej ilości wizyt w tym kraju (Kuru, 2015). W 2011 r. Ankara zaproponowała 
podpisanie porozumienia „Shamgen”, które miało być odpowiednikiem europejskiego Schengen, tworzącego regionalny ruch bezwizowy pomiędzy Turcją, Iranem, Irakiem i Syrią, a w przyszłości dołączyć miały Jemen, Liban, Libia, Maroko i Tunezja. Porozumienia te miały wzmocnić współpracę gospodarczą w regionie i przyczynić się do rozwoju sektora turystycznego (Grigoriadis, 2014, s. 166). Należy podkreślić, że ta ekspansywna rola Ankary w odbudowaniu regionalnego zaufania oraz wzmocnienia współpracy pomiędzy muzułmańskimi państwami Bliskiego Wschodu była możliwa dzięki pogorszeniu jej relacji z Izraelem. Od 2009 r. Erdoğan wyrażał się coraz bardziej krytycznie o polityce Izraela wobec Autonomii Palestyńskiej. Wydarzenia związane z izraelskim atakiem w 2010 r. na turecką „flotyllę wolności” wiozącą pomoc dla palestyńskich mieszkańców blokowanej Strefy Gazy stały się apogeum kryzysu w stosunkach na linii Ankara-Tel-Awiw (Marcou, 2013, s. 2). Pogorszenie tych relacji automatycznie, zdaniem Ankary, predestynowało Turków do przejęcia roli lidera państw islamskich zabiegającego o polepszenie bytu Palestyńczyków.

Sami politycy tureccy zachłyśnięci dotychczasowymi ekonomicznymi i politycznymi sukcesami zaczęli wyraźnie aspirować do określania swojego państwa jako wschodzącego mocarstwa. Emanacją tej samooceny były kolejne ambitne cele Erdoğana: uplasowanie się w pierwszej dziesiątce najbardziej rozwiniętych gospodarczo państw świata do 2023 r. oraz osiagnięcie pozycji drugiej gospodarki w Europie (za Niemcami) do 2050 r. Najbardziej dalekosiężnym tureckim celem było osiagnięcie statusu mocarstwa światowego w ciągu najbliższych kilku dekad (Barrinha, 2014, s. 166).

Swoistym egzaminem możliwości oddziaływania Turcji w regionie stała się arabska wiosna, która rozpoczęła się pod koniec 2010 r. Pełniący wówczas funckję premiera Erdoğan zaangażował się w rozwiązywanie problemów politycznych w państwach północnej Afryki i Bliskiego Wschodu, przez które przechodziła rewolucyjna fala. Jego aktywność była widoczna w Tunezji, Libii i Egipcie, gdzie występował w roli przywódcy państwa demokratycznego, nowoczesnego, ale zarazem muzułmańskiego, mogącego stanowić model dla tworzenia podwalin konstytucyjnych w tych krajach. Turcja zaczęła w regionie kreować się na lidera sunnickiego islamu, godząc tym samym w interesy szyickiego Teheranu (Gürzel, 2014), ale także wywołując niechęć innego gracza w regionie, Arabii Saudyjskiej. Erdoğan szczególnie zaangażował się w Syrii, gdzie wsparł antyrządową opozycję, domagając się początkowo przeprowadzenia reform przez prezydenta Baszara al Asada, a następnie zażądał jego ustąpienia. Politycy tureccy liczyli na to, że dzięki wsparciu opozycji i obaleniu reżimu Asada uda im się w przyszłości efektywnie oddziaływać na wewnętrzną sytuację w Syrii. Okazało się jednak, że ambicje tureckie zderzyły się z interesami Rosji i Iranu, które wsparły dyktatora z Damaszku (Onis, 2014, s. 211). Drugim państwem, w którego wewnętrzną sytuację zaangażował się Erdoğan był Egipt. Tu także lider turecki wezwał Mubaraka do ustapienia, a po jego obaleniu wspierał prezydenta Morsiego popieranego przez Bractwo Muzułmańskie. Jednak działania tureckie w Egipcie także zakończyły się fiaskiem, kiedy po obaleniu Morsiego władze przejął niechętny Turcji gen. Sisi, który został nowym prezydentem kraju, a Bractwo Muzułmańskie, z którym sympatyzował Erdoğan, zdelegalizowano. Okazało się, że turecka polityka zagraniczna oparta na zasadzie ,zero problemów z sąsiadami” nie może być realizowana ze względu na niestabilne środowisko międzynarodowe na Bliskim Wschodzie. Ambicje 
tureckie budowania mocarstwowej pozycji w regionie zderzyły się z oporem innych graczy w regionie.

Wydarzenia międzynarodowe związane z następstwami Arabskiej Wiosny zdecydowanie przerosły możliwości tureckiej polityki zagranicznej. Turcja przeszacowała swoją pozycję i swoje możliwości odgrywania wiodącej roli w regionie. Do Turcji dotarł w 2009 r. kryzys ekonomiczny, pogorszyły się jej wskaźniki makroekonomiczne, rozwój gospodarczy uległ spowolnieniu. Okazało się, że kraje arabskie, przez które przeszła Arabska Wiosna nie są raczej zainteresowane modelem tureckim - Turcja jest bowiem dla nich zbyt świeckim krajem (Turkey's Role, 2013, s. 10). Zainteresowanie państw arabskich koncentrowało się na źródłach wcześniejszego boomu gospodarczego i podniesienia jakości życia w Turcji, a nie na naśladowaniu modelu politycznego państwa znad Bosforu.

Fiasko tureckiej polityki zagranicznej w regionie Bliskiego Wschodu pokazało, że Ankara nie była przygotowana do zadania, które chciała wypełnić w swoim otoczeniu. Decyzja o podjęciu aktywnej roli w wewnętrznych rozgrywkach swoich sąsiadów i uwikłanie się w konflikty domowe była bardzo ryzykowna i jak się okazuje oparta na niedostatecznej, a raczej niewłaściwej diagnozie sytuacji. To może świadczyć tylko i wyłącznie o słabości kadr i braku doświadczenia w ocenie polityki bliskowschodniej członków AKP. Otwarcie się na bliższe kontakty z państwami Bliskiego Wschodu związane jest z olbrzymim ryzykiem i wymaga niezwykłej zręczności politycznej i doświadczonej dyplomacji, która radziłaby sobie w wirze rozbieżnych politycznych i religijnych interesów państw muzułmańskich. Jak podaje Ahmet Kuru „na 135 tureckich dyplomatów pracujących w ponad dwudziestu arabskich państwach, zaledwie 6 mówiło po arabsku" (Kuru, 2015, s. 102) w czasie wydarzeń Arabskiej Wiosny. Zdecydowany przerost ambicji Ankary nad możliwościami wpływania na bieżącą politykę międzynarodową obnażył słabość Turcji, która niepotrzebnie dała się uwikłać w konflikty religijne Bliskiego Wschodu. Można zaryzykować stwierdzenie, że Turcja skompromitowała się i ośmieszyła na arenie międzynarodowej. Jeszcze do niedawna Turcja postrzegana jako świecki, stabilny i przewidywalny kraj stała się państwem bliskowschodnim, ale rozumianym jako niestabilny, nieprzewidywalny oraz konfliktogenny kraj zamieszkały przez ludność muzułmańską. Oczywiście Turcja próbuje ratować swój wizerunek międzynarodowy w regionie, próbując porozumieć się z Rosją i Iranem. Jednak trudno uwierzyć w długotrwałość tego porozumienia ze względu na kruchość systemu międzynarodowego na Bliskim Wschodzie, wynikającego z toczących się wojen domowych, konfliktów religijnych i ambicji innych graczy świata muzułmańskiego.

\section{Zakończenie - perspektywy zagranicznej orientacji Turcji}

Rezygnacja, a może tymczasowe osłabienie kierunku prozachodniego, czy też proeuropejskiego w polityce zagranicznej Turcji pod rządami AKP przyniosło Ankarze same straty. Turcja przestała być postrzegana przez dotychczasowych sojuszników jako lojalny partner, było to szczególnie widoczne, kiedy w 2014 r. odmówiła współpracy z USA w ramach kształtowania koalicji przeciwko tzw. Państwu Islamskiemu. 
Amerykanie oskarżali także Ankarę o wspieranie Dżabat al-Nusry organizacji dżihadistów powiązanych z Al-Kaidą, która działała na terenie Syrii. Pojawiły się nawet propozycje USA, aby zrezygnować z bazy NATO w tureckim Incirliku i otworzyć nową bazę powietrzną na terenie autonomii kurdyjskiej w Iraku (Park, 2015, s. 581).

Swoistym wyrazem braku zaufania do Turków było odbycie pierwszej międzynarodowej wizyty w 2017 r. przez prezydenta Donalda Trumpa do Arabii Saudyjskiej i Izraela. Podróż Trumpa na Bliski Wschód wyraźnie wskazała, że jest to region szczególnie ważny w polityce USA, jednak pominięcie w niej Ankary i wskazanie na Saudów, jako głównych sojuszników Amerykanów w regionie można zinterpretować jako degradację Turcji w systemie bliskowschodnich powiązań amerykańskich. Tym bardziej, że Arabię Saudyjską aspirującą także do roli mocarstwa regionalnego Turcy traktują jako rywala, konkurują $\mathrm{z}$ nią także w zakresie przywództwa w świecie islamu sunnickiego. Także wizyta Trumpa w Izraelu, będącym w sporze z Ankarą, jest symptomatyczna i można ją odczytać jako kolejny „policzek” dla Turcji. Szukanie przeciwwagi regionalnej w postaci zacieśnienia kontaktów Ankary z Teheranem może być krótkowzroczne i nieprzewidywalne. Już dotychczasowa polityka Ankary zbliżania się do Iranu wzbudziła krytykę USA oraz sojuszników europejskich obawiających się irańskiego programu atomowego. Jeżeli Iran stworzyłby własną bombę atomową naruszyłby zdecydowanie regionalną, choć bardzo kruchą, równowagę sił i wówczas pozycja Turcji byłaby bardzo słaba. Dopiero wówczas otoczenie Turcji stałoby się skrajnie niebezpieczne dla obywateli tego kraju. Tym bardziej dziwią krótkowzroczne decyzje Erdoğana wspierającego zniesienie sankcji na Iran.

Turcja coraz bardziej dystansuje się od polityki NATO, ale też pogarsza swoje relacje z Unią Europejską. Powodów tego pogorszenia jest kilka. Po pierwsze, Turcja świadomie „wyeksportowała” problem bliskowschodnich uchodźców do Europy w 2015 r., przestając kontrolować swoje zewnętrzne granice i umożliwiając exodus migrantów ze swojego terytorium do Unii Europejskiej. Prezydent Erdoğan zdając sobie sprawę, że uchodźcy destabilizują sytuację polityczną w wielu państwach europejskich postanowił wykorzystać ten fakt do zmuszenia Brukseli do ustępstw. W marcu 2016 r. podpisano porozumienie pomiędzy UE a Turcją, które spowodowało wstrzymanie napływu uchodźców do Europy. Turcja uzyskała w zamian za to pomoc finansowa, obietnicę zniesienia wiz dla swoich obywateli zmierzających na teren UE oraz wznowienia negocjacji akcesyjnych. UE zobowiązała się do przyśpieszenia procesu liberalizacji wizowej dla obywateli tureckich po spełnieniu warunków wskazanych przez Komisję Europejską. Początkowo termin liberalizacji był wyznaczony na koniec czerwca 2016 r., jednak ze względu na niewypełnienie kryteriów przez Turcję do tej pory nie doszło do zniesienia wiz. Porozumienie zakładało także intensyfikację procesu akcesyjnego Turcji, w ramach którego doszło do otwarcia rozdziału negocjacyjnego dotyczącego przepisów finansowych i budżetowych i zaplanowano w najbliższej przyszłości otwarcie kolejnych. Należy jednak pamiętać, że Unia Europejska zgadzając się na żądania Turcji podkreślała, że Ankara równocześnie musi wprowadzać u siebie i respektować fundamentalne zasady prawa europejskiego.

Drugim elementem wpływającym niekorzystnie na relacje unijno-tureckie była krytyka Erdoğana skierowana do polityków europejskich za ich brak reakcji i wsparcia w czasie próby puczu przeprowadzonego w lipcu 2016 r. W jego opinii Zachód nie 
zachował się lojalnie wobec Ankary. Jego wściekłość na postawę liderów europejskich się wzmogła, gdy skrytykowali oni kroki podjęte prze rząd turecki przeciwko opozycji. Erdoğan postanowił bowiem wykorzystać nieudany pucz jako pretekst do rozprawienia się z przeciwnikami politycznymi. Dochodziło do represji i masowych aresztowań osób ze środowiska opozycyjnego wobec AKP. Politycy europejscy reagując na to wyraźne łamanie zasad demokracji i rządów prawa podkreślili, iż te kroki oddalają Turcję od UE i utrudniają prowadzenie dalszych negocjacji akcesyjnych, ale także uniemożliwiają zniesienie wiz dla obywateli tureckich. W konsekwencji w retoryce Erdoğana ponownie pojawił się element szantażu, gdyż zaczął grozić odstapieniem Turcji od porozumienia w sprawie kontroli napływu uchodźców, grożąc użyciem tej „broni demograficznej”.

Trzecim elementem negatywnie wpływającym na stosunki Turcji z UE jest kampania Erdoğana prowadzona na potrzeby wewnętrzne, a związana z negacją postanowień Traktatu z Lozanny z 1923 r. ustalającego granice zewnętrzne Turcji. Ta polityka rewizjonizmu granic godzi w interesy jednego z członków UE (nie wspominając już o Cyprze), mianowicie Grecji, kwestionując przynależność części wysp Morza Egejskiego do Hellady. Polityka ta przypomina Europie także wydarzenia poprzedzające II wojnę światową, która była wielką katastrofą w dziejach ludzkości. Co prawda Erdoğan szermuje hasłami rewizjonistycznymi, głównie na potrzeby scalenia własnego elektoratu w Turcji, jednak niebezpiecznych skutków tej polityki dla wymiaru międzynarodowego trudno przewidzieć. $Z$ pewnością te hasła rewizjonistyczne są narzędziem gry politycznej w kontekście bardzo niestabilnej sytuacji w Iraku i możliwości rozpadu tego państwa, a zatem przejęcia kontroli przez Turcję nad roponośnym regionem Mosulu, który zdaniem Erdoğana powinien należeć do Turcji.

Obserwując współczesną politykę Ankary należy podkreślić, że z perspektywy europejskiej Turcja staje się coraz bardziej trudnym, nieprzewidywalnym i problemowym sąsiadem Unii Europejskiej. Decyzje Erdoğana w zakresie polityki zewnętrznej coraz trudniej zrozumieć i wytłumaczyć. Można odnieść wrażenie, że Turcja w tej chwili nie posiada żadnej długofalowej strategii budowania relacji ze swoim otoczeniem. Biorąc pod uwagę uzyskanie wsparcia społeczeństwa w referendum dla jego wizji systemu prezydenckiego, autorytarne zapędy prezydenta Turcji, ograniczenie wolności słowa, roli mediów, podporządkowanie sądownictwa, te wszystkie elementy wskazują że Turcja oddala się od dotychczasowych sojuszników w Europie. Wkomponowuje się coraz bardziej w nieprzewidywalne środowisko Bliskiego Wschodu, uwikłane w konfrontacje militarne i konflikty religijne. Ten antyeuropejski dryf Turcji jest o tyle trudny do zrozumienia, że oprócz Zachodu pozostałe kierunki w polityce zagranicznej dotyczą obszarów wyjątkowo niestabilnych i konfliktogennych. Dotyczy to nie tylko Bliskiego Wschodu i Zatoki Perskiej, ale także państw Kaukazu i Azji Środkowej, gdzie Turcja siłą rzeczy będzie musiała rywalizować z odradzającą się ekspansywną polityką Rosji.

Także wizja budowania własnej potęgi w oparciu o położenie geograficzne i określania się jako tzw. centrum dystrybucji (hub) surowcowej wymaga stabilnego otoczenia dla Turcji. W celu pełnienia takiej roli trzeba mieć przewidywalnych dostawców oraz odbiorców. Przede wszystkim należy być postrzeganym przez kontrahentów jako stabilny, wiarygodny i przewidywalny partner, a to jest cecha, której obecnie Turcji 
szczególnie brakuje. Oczywiście odbiorcami surowców od Turcji mogą być wysokorozwinięte państwa europejskie, jednak należy podkreślić, że wyjątkowość Ankary jako huba energetycznego może być bardzo ograniczona i krótka. Na tym polu rośnie coraz większa konkurencja, chociażby ogromne złoża węglowodorów odkryte na szelfie kontynentalnym Izraela.

Należy podkreślić, że pod rządami AKP Turcja oddaliła się od tzw. „,rodziny europejskiej”, jeżeli w ogóle kiedykolwiek była jej członkiem (Buhari, 2009, s. 95). Ankara nie ma szans na akcesję do Unii Europejskiej, jednak to nie powinno wywoływać u niej reakcji „obrażenia się” i odwracania ,plecami” do Zachodu. Turcję i Unię Europejską dzieli przepaść kulturowa, która jest ważna w procesach integracji europejskiej. Samo określanie się Ankary jako pomostu pomiędzy Wschodem a Zachodem wskazuje, że politycy znad Bosforu nie do końca utożsamiali się z dziedzictwem europejskim. Turcję łączą jednak z Unią Europejską silne kontakty gospodarcze (unia celna), oba rynki są ze sobą związane i komplementarne. Turcja może pozostać bliskim partnerem Unii bez pełnej akcesji, uzyskując status uprzywilejowany i wykorzystać te relacje do budowy swojego prestiżu wśród państw Bliskiego Wschodu. Dryf antyeuropejski, odwracanie się od jedynego w tej chwili stabilnego i przewidywalnego partnera dla Turcji byłoby katastrofalne w dalszej perspektywie, szczególnie w sytuacji niekończących się wojen, kryzysów i napięć w jej wschodnim i południowym otoczeniu.

\section{Bibliografia}

Adamczyk A. (2002), Cypr. Dzieje polityczne, Warszawa.

Adamczyk A. (2009), Wpływ unormowania stosunków grecko-tureckich na stabilizację bezpieczeństwa we wschodniej części Morza Śródziemnego, w: Bezpieczeństwo Międzynarodowe. Wyzwania i zagrożenia XXI wieku, red. P. Olszewski, T. Kapuśniak, W. Lizak, Radom.

Agnantopoulos A. (2013), The Europeanization of national foreign Policy: explaining Greek support for Turkey's EU accession. „, Southeast European and Black Sea Studies”, nr 1.

Ambroziak A. A. (2014), The European Union's Trade with Turkey under the Customs Union, w: Poland and Turkey in Europe - Social, Economic and Political Experiences and Challenges, red. A. Adamczyk, P. Dubel, Warszawa.

Altunisik B. (2013), The Middle East In Turkey-USA Relations: Managing the Alliance, ,Journal of Balkan and Near Eastern Studies", vol. 15, nr 2.

Aydin M. (2014), Turkish Policy towards the Wider Black Sea and the EU Connection, ,Journal of Balkan and Near Eastern Studies", vol. 16, nr 3.

Buhari D. (2009), Turkey-EU Relations: The Limitation of Europeanisation Studies, „The Turkish Yearbook of International Relations, vol. 40.

Barburska O. (2016), Argument sity czy siła argumentów? Unia Europejska w stosunkach międzynarodowych jako 'soft power', „Rocznik Integracji Europejskiej”, nr 10.

Barburska O., Milczarek D. (2013), Historia integracji europejskiej w zarysie, Warszawa.

Barrinha A. (2014), The Ambitious Insulator: Revisiting Turkey's Position In Regional Security Complex Theory, „Mediterranean Politics”, vol. 19, nr 2.

Criss N. B. (2013), The USA-Turkey-Middle East: From the 20th Century to the Present, „Journal of Balkan and Near Eastern Studies", vol. 15, nr 2.

Cyr A. (2015), Turkey's Continuing Role as a Pivotal Ally in a Rapidly Changing Region, Foreign Policy Research Institute, Philadelphia. 
Gonlübol M. (1999), NATO and Turkey. An Overall Appraisal, „The Turkish Yearbook”, vol. XI.

Grigoriadis I. (2014), Turkey's foreign policy activism: vision continuity and reality checks, „Southeast European and Black Sea Studies", vol. 14, nr 2.

Gürzel A. (2014), Turkey's Role as a Regional and Global Player and its Power Capacity: Turkey's Engagement with other Emerging Countries, „Revista de Sociologia e Politica”, nr 50.

Gynay D., Renda K. (2014), Usages of Europe in Turkish Foreign Policy towards the Middle East, „Journal of Balkan and Near Eastern Studies”, vol. 16, nr 1.

Guvenc S., Ozel S. (2012), NATO and Turkey in the post-Cold world: between abandonment and entrapment, „Southeast European and Black Sea Studies”, vol. 12, nr 4.

Kuru A. (2015), Turkey's Failed Policy towards the Arab Spring: Three Levels of Analysis, „Mediterranean Quarterly", nr 3, September.

Marcou J. (2013), Turkey's Foreign Policy: Shifting Back to the West after a Drift to the East?, Turkey Policy Brief Series, International Policy and Leadership Institute (TEPAV), http://www. tepav.org.tr/upload/files/1365165523-5.Shifting_Back_to_the_West_after_a_Drift_to_the_ East.pdf.

Martin L. G. (2004), Turkey's Middle East Foreign Policy w: The Future of Turkish Foreign Policy, red. L. G. Martin, D. Keridis, Harvard University, Cabridge-Massachusetts-London.

Misztal M. (2013), Historia Cypru, Kraków.

Onis Z. (2014), Turkey and the Arab Revolutions: Boundaries of Regional Power Influence In a Turbulent Middle East, „Mediterranean Policy”, vol. 19, nr 2.

Osiewicz P. (2015), 10 lat negocjacji akcesyjnych Turcji z Uniq Europejskq. Analiza postępów w obszarze kryteriów politycznych na podstawie raportów Komisji Europejskiej, „Rocznik Integracji Europejskiej", nr 9.

Osiewicz P. (2013), Konflikt cypryjski, Warszawa.

Osiewicz P. (2006), Spory grecko-tureckie w basenie Morza Egejskiego w: Spory - konflikty zbrojne - terroryzm. Dysfunkcjonalne czynniki współczesnych stosunków międzynarodowych, red. W. Malendowski, Poznań.

Outzen R. (2012), From Crisis to Cooperation. Turkey's Relations with Washington and NATO, „Policy Notes", nr 12.

Park B. (2015), Turkey's isolated stance: an ally no more, or just the usual turbulence?, „International Affairs", vol. 91, nr 3.

Turkey's Role as a Regional Power: Its Scope, Challenges and Future (2013), Quilliam Report, Quilliam Foudation, July, http://www.quilliamfoundation.org.

Stępniewski T. (2011), Geopolityka Morza Czarnego w postzimnowojennym świecie, Lublin.

Strategia Rozszerzenia UE (2015), Komunikat Komisji do Parlamentu Europejskiego, Rady, Europejskiego Komitetu Ekonomiczno-Społecznego i Komitetu Regionów, COM(2015) 611 final, Bruksela 10.11.2015.

Sztubert J. (2011), Znaczenie Turcji dla relacji Unii Europejskiej z Bliskim Wschodem, w: red. A. Szymański, Turcja i Europa. Wyzwania i szanse, Warszawa.

Szymański A. (2011), Turcja i Europa. Wyzwania i szanse, Warszawa.

Szymański A. (2008), Między islamem a kemalizmem. Problem demokracji w Turcji, Warszawa.

Tuysuzoglu G. (2014), Strategic Depth: A Neo-Ottomanist Interpretation of Turkish Euroasianism, „Mediterranean Quarterly”, Spring.

Wódka J. (2013), Polityka zagraniczna ,nowej Turcji”. Implikacje dla partnerstwa transatlantyckiego, Warszawa.

Yanik L. K. (2011), Constructing Turkish ,exceptionalism”: Discourses of liminality and hybridity in post-Cold War Turkish foreign policy, „Political Geography”, vol. 30. 
Yesilyurt N., Akdevelioglu A. (2009), Turkey's Middle East Policy under the JDP Rule, „The Turkish Yearbook of International Relations, vol. 40.

Zajączkowski K. (2011), Uwarunkowania ekonomiczne a członkostwo w Unii Europejskiej, w: red. A. Szymański, Turcja i Europa. Wyzwania i szanse, Warszawa.

\section{Streszczenie}

Turcja od czasu powstania republiki w 1923 r. ukierunkowana była na westernizację i budowanie ścisłych kontaktów z państwami europejskimi. Także po zakończeniu drugiej wojny światowej i powstaniu systemu dwublokowego zadecydowała o członkostwie w bloku państw kapitalistycznych jako sojusznik w ramach NATO oraz aspirant do członkostwa we Wspólnotach Europejskich. Rozpad systemu jałtańskiego i powstanie układu multipolarnego stał się wyzwaniem dla kształtowania nowych kierunków w polityce zagranicznej Turcji, osłabił równocześnie jej związki z Zachodem. Ankara uwierzyła bezkrytycznie we własny potencjał i możliwości pełnienia roli mocarstwa regionalnego i państwa euroazjatyckiego budującego swoje wpływy na obszarze dawnego Imperium Otomańskiego. Wydaje się jednak, że bezkrytyczna samoocena i wygórowane ambicje przerosły możliwości polityków tureckich.

Słowa kluczowe: Turcja, Unia Europejska, Bliski Wschód, polityka zagraniczna

\section{Quo Vadis Turkey - Is This The End of European Direction in Turkey's Foreign Policy?}

\section{Summary}

Since the founding of the republic in 1923, Turkey has been geared towards westernization and building close contacts with European states. Even after the end of World War II and the emergence of the bipolar system, it decided on membership of the capitalist bloc as an ally within NATO and aspired to membership in the European Communities. The disintegration of the Yalta system and the creation of the multipolar system became a challenge for shaping new directions in Turkey's foreign policy, and at the same time weakened its links with the Western allies. Ankara has started to believe uncritically in its own potential and capacity to act as a regional power and Eurasian state that was building its influence in the area of the former Ottoman Empire. It seems, however, that uncritical self-esteem and excessive ambition have outstripped the possibilities of Turkish politicians.

Key words: Turkey, European Union, Middle East, foreign policy 
